\title{
False-Positive Outcome and Drug Residue in Milk Samples Over Withdrawal Times
}

\author{
J. H. Kang, ${ }^{1}$ J. H. Jin, ${ }^{2}$ and F. Kondo ${ }^{1}$ \\ ${ }^{1}$ Department of Veterinary Public Health and \\ ${ }^{2}$ Department of Veterinary Microbiology, Faculty of Agriculture, Miyazaki University, \\ Kibanadai-Nishi, Gakuen, Miyazaki-shi, 889-2192, Japan
}

\begin{abstract}
This study was conducted to identify false-positive outcomes and drug residues in milk samples over withdrawal times and to determine whether the positive results were caused by drug residues or natural inhibitors. A total of 73 milk samples over withdrawal times after the last intramammary infusion were collected from each treated quarter of cows and tested using the Delvotest SP assay. Reading time was 150, 165, and 180 min, and results of samples were recorded according to the color of the well containing the control milk sample. There were 24, 20, and 12 positive samples at the reading times of 150, 165, and $180 \mathrm{~min}$, respectively. All 24 positive milk samples were heated at $82^{\circ} \mathrm{C}$ for $5 \mathrm{~min}$ and retested to verify that the positive results were caused by drug residues or natural inhibitors. Twentyone samples that exhibited positive results were negative after heat treatment, and drug residues were not identified by LacTek and Charm tests. However, 3 samples that exhibited positive results from heat treatment of $82^{\circ} \mathrm{C}$ were positive for drugs. In our study, most positive results $(89 \%)$ in the milk samples over withdrawal times were false-positive results by natural inhibitors. Moreover, the heat treatment is a fast, simple, and inexpensive method to remove false-positive results and has no effect on positive samples containing drugs. We suggest that heat treatment before screening tests is an effective way to reduce false-positive results in the milk samples.
\end{abstract}

(Key words: Delvotest SP assay, heat treatment, withdrawal time, natural inhibitor)

\section{INTRODUCTION}

Because the presence of drug residues in milk is undesirable, a drug residue-free milk supply is an important

Received June 5, 2002.

Accepted February 10, 2003.

Corresponding author: F. Kondo; e-mail: a0d902u@cc.miyazaki-u. ac.jp. issue in the dairy industry. The test for drug residues in milk is performed by several methods, such as microbial growth inhibition assays, microbial receptor assays, receptor binding assays, immunologic assays, enzymatic assays, and chromatographic analysis (Mitchell et al., 1998). The Delvotest assay, one of the microbial growth inhibition assays, is a simple, sensitive, and broadly drug-detecting test system. This assay is based on the rapid growth and acid production of the test organism, Bacillus stearothermophilus var. calidolactis (Katz, 1982; Kelley, 1982). Several studies have reported that false-positive results occurred on samples containing no drug in the test using the Delvotest assay. These false-positive results are high in the milk sample taken from individual cows having mastitis or colostrums (Oliver et al., 1984; Cullor et al., 1992; 1994; Tyler et al., 1992; Sischo and Bruns, 1993; Van Eenennaam et al., 1993; Andrew, 2001; Gibbons-Burgener et al., 2001). Tyler et al. (1992) found that the percentage of falsepositive results from the Delvotest $\mathrm{P}$ assay was $45 \%$ in the milk samples taken from cattle with experimental endotoxin-induced mastitis. Van Eenennaam et al. (1993) reported, in the case of cattle with naturally occurring clinical mastitis, that $37.7 \%$ false-positive results from the Delvotest $\mathrm{P}$ assay were identified. However, a false-positive result is low in bulk tank and tank-lorry samples because false-positive samples can be diluted in the larger volume of a bulk tank or tanklorry (Kang and Kondo, 2001). Moreover, Halbert et al. (1996) reported that false-positive results of the Delvotest assay in the milk samples taken from cows having no clinical mastitis was very low.

High levels of natural inhibitors are present in mastitic milk and in colostrums, and they can cause falsepositive results in the microbial growth inhibition assays (Kosikowski and O'Leary, 1963; Harmon et al., 1975; 1976; Nickerson, 1985; Carlsson and Björch, 1987; Carlsson et al., 1989; Hillerton et al., 1999). Carlsson et al. (1989) found that a false-positive result in the Delvotest assay correlated with an increase in lactoferrin and lysozyme concentrations. Not only natural inhibitors, but incubator type (Suhren and Beukers, 1999), component of milk (Andrew, 2000; 2001), and 
method of sample collection (Andrew et al., 1997) have an influence on the result of the Delvotest assay. In a previous study, we identified the importance of reading time in the Delvotest assay. The occurrence of a falsepositive result was high when the plate was cultured for 150 min rather than 165 and 180 min (Kang and Kondo, 2001).

Drugs are widely used in treatment of various bacterial infections in dairy cattle, including mastitis. The recommended withholding period following treatment should be followed to avoid drug residue in milk. However, sometimes drugs can be contained in milk over withdrawal times, resulting in positive test results for drug residues (Mercer et al., 1970; Allison, 1985; Booth and Harding, 1986; Seymour et al., 1988a; 1988b; Oliver et al., 1990; McEwen et al., 1992). Moreover, natural inhibitors in the milk of cows with mastitis are increased and kept at high concentrations for several days (Harmon et al., 1975; 1976; Nickerson, 1985). The increased natural inhibitors can lead to false-positive results in the use of bioassays based on bacterial growth inhibition, inclusive of the Delvotest assay, on the milk samples over withdrawal times. Therefore, it is important to evaluate that the positive results in milk over withdrawal times are caused by drug residues or natural inhibitors.

This study was performed to identify false-positive outcomes and drug residues in the milk samples over withdrawal times. Our study also evaluated that the positive results were due to drug residues or natural inhibitors.

\section{MATERIALS AND METHODS}

\section{Experimental Cows and Sample Collection}

Among lactating Holstein cows with clinical mastitis, 64 cows treated by intramammary infusion were used and cows treated by multiple routes of administration (e.g., intramammary plus intramuscular or intravenous administration) with more than one drug were excluded. The treatment of cows was carried out by the farmer or veterinarian after sampling the affected quarter and after milking. Before administering drug to quarters, teat ends were thoroughly disinfected with a pledget moistened with $70 \%$ alcohol for a few seconds. The affected quarters of cows were infused with the contents of syringe per quarter according to the manufacturer's recommendation. The types and withdrawal times of drugs used in this study were based on the drug label instructions and are presented in Table 1. A total of 73 foremilk samples over withdrawal times were collected from treated quarters of cows after the last drug treatment. The collected milk samples were
Table 1. Types and withdrawal times of drugs used in this study.

\begin{tabular}{lll}
\hline Types & $\begin{array}{l}\text { No. used in } \\
\text { treatment }\end{array}$ & $\begin{array}{l}\text { Withdrawal } \\
\text { times }(d)\end{array}$ \\
\hline Beta-lactams & 48 & $2-5$ \\
Tetracyclines & 15 & 3 \\
Sulfonamides & 8 & $2-3$ \\
Aminoglycosides & 2 & 3 \\
\hline
\end{tabular}

immediately kept at $<5^{\circ} \mathrm{C}$ (no freezing) and examined within $24 \mathrm{~h}$.

\section{Test of Samples Using the Delvotest SP Assay}

A multiplate-type Delvotest SP (Royal Gist-brocades NV, Delft, The Netherlands) was prepared for the examination of samples. A nutrient tablet and $0.1 \mathrm{~mL}$ of samples were added to each test well. The plates were incubated in a water bath with a controlled temperature of $64.0 \pm 0.5^{\circ} \mathrm{C}$. Plate results were read at 150 , 165, and $180 \mathrm{~min}$. According to comparisons with the color of the well containing the control milk sample, results of each sample were recorded by 4 types: A, purple throughout whole agar; B, slightly more yellow than the control sample; C, moderately more yellow than the control sample; and D, yellow throughout whole agar or the same as the color of the control sample. The UHT market milk was used as the negative control, and it was subjected to the Delvotest SP assay, the Charm test (Charm Science Inc., Malden, MA), and the LacTek test (Idxx Laboratories, Inc., Westbrook, $\mathrm{ME}$ ) before use as the control sample.

\section{Heating Test for Confirmation of the Presence of Inhibitors}

In a previous study (Kang and Kondo, 2001), the method of heat treatment at $82^{\circ} \mathrm{C}$ for 5 min reported by Kosikowski and O'Leary (1963), and heat treatment at 90 and $100^{\circ} \mathrm{C}$ for 5 min were used to confirm the presence of natural inhibitors. All methods of heat treatment were effective on the removal of natural inhibitors and had no influence on positive samples. In this study, therefore, heat treatment at $82^{\circ} \mathrm{C}$ for $5 \mathrm{~min}$ was used to confirm the presence of natural inhibitors. After heating at $82^{\circ} \mathrm{C}$ for 5 min, milk samples were rapidly cooled to $20^{\circ} \mathrm{C}$ with cold water.

\section{Confirmation of Drugs in Samples and SCC}

Charm test and LacTek test were used to confirm the presence of drugs in samples that exhibited positive results (color-type results $\mathrm{A}$ to $\mathrm{C}$ ). Both tests were performed according to the recommendations of the manufacturer. 
Table 2. Results of the Delvotest SP assay on the milk samples over withdrawal times.

\begin{tabular}{llcc}
\hline $\begin{array}{l}\text { Reading } \\
\text { time (h) }\end{array}$ & $\begin{array}{l}\text { Color } \\
\text { results }^{1}\end{array}$ & $\begin{array}{l}\text { Before } \\
\text { heat } \\
\text { treatment }\end{array}$ & $\begin{array}{l}\text { After } \\
\text { heat } \\
\text { treatment }\end{array}$ \\
\hline 2.50 & A & 3 & 3 \\
& B & 10 & 0 \\
& C & 11 & 0 \\
2.75 & D & 49 & 70 \\
& A & 3 & 3 \\
& B & 4 & 0 \\
3.00 & C & 13 & 0 \\
& D & 53 & 70 \\
& A & 2 & 2 \\
& B & 1 & 0 \\
& C & 9 & 70 \\
\hline
\end{tabular}

${ }^{1} \mathrm{~A}$, purple throughout whole agar; $\mathrm{B}$, slightly more yellow than the control sample; C, moderately more yellow than the control sample; and $\mathrm{D}$, yellow throughout whole agar or the same as the color of the control sample.

${ }^{2}$ The heat treatment was performed at $82^{\circ} \mathrm{C}$ for $5 \mathrm{~min}$.

The SCC was detected using a Somacount 300 system (Bentley Instruments, Inc., Chaska, MN). Tests were done according to the manufacturer's recommendations.

\section{Statistical Analysis}

Somatic cell count results of negative, false-positive, and positive samples are expressed as the mean and standard deviation. All SCC determinations were done in duplicate. Statistical analysis comprised significance testing of the difference between means using a Student's $t$-test at the level of $P<0.05$.

\section{RESULTS}

In the present study, the majority of drugs used for the treatment of mastitis were beta-lactams, penicillins, and cephalosporins. The recommended withdrawal times of drugs ranged from 2 to $5 \mathrm{~d}$ (Table 1). Moreover, the color results of the Delvotest SP assay were recorded as 4 types (A, B, C, and D) (Table 2). Hillerton et al. (1999) reported that a partial purple color result (mainly yellow with some purple), which is similar to a color-type $\mathrm{C}$ of our study was shown at 8 $\mu \mathrm{g} / \mathrm{kg}$ of cephalonium. On this basis, because drugs can be contained in the color-type $\mathrm{C}$, the results of colortype $\mathrm{A}$ to $\mathrm{C}$ in our study are considered positive results.

Seventy-three milk samples beyond withdrawal times were collected from cows treated by intramammary infusions and tested using the Delvotest SP assay. Before heat treatment at $82^{\circ} \mathrm{C}$ for $5 \mathrm{~min}$, the number of samples exhibiting positive results (color types A to C) was 24,20 , and 12 at the reading times of 150,165 , and $180 \mathrm{~min}$, respectively. All 24 positive milk samples were heated at $82^{\circ} \mathrm{C}$ for $5 \mathrm{~min}$ and retested to determine whether the positive results were caused by drug residues or natural inhibitors. Twenty-one milk samples that exhibited color types $\mathrm{B}$ and $\mathrm{C}$ at a reading time of 150 min were color-type $\mathrm{D}$ following heat treatment at $82^{\circ} \mathrm{C}$ for $5 \mathrm{~min}$. But, 3 samples continued to show positive results after heat treatment at $82^{\circ} \mathrm{C}$ for $5 \mathrm{~min}$. In LacTek and Charm tests to confirm the presence of drugs, the 3 milk samples that exhibited color-type A and $\mathrm{B}$ from heat treatments of $82^{\circ} \mathrm{C}$ were positive for drug (2 samples in beta-lactams and 1 sample in tetracyclines). But, drugs were not identified in 21 milk samples exhibiting color-type D following heat treatment (Table 2). Therefore, we concluded that the positive results of 21 samples were caused by natural inhibitors contained in milk samples.

In the case of reading time, the occurrence of falsepositive results was high when the plate was cultured for 150 min ( 21 samples) rather than 165 (17 samples) and $180 \mathrm{~min}$ ( 9 samples). These results show that reading time has an important influence on the result of the Delvotest SP assay (Table 2).

After treatment, the SCC of negative, false-positive, and positive samples averaged $2.447,5.368$, and 4.752 $\times 10^{3}$ cells $/ \mathrm{mL}$, respectively. The SCC in false-positive and positive samples was higher compared with that in negative samples $(P<0.05)$ (Table 3 ).

\section{DISCUSSION}

Intramammary infusion products containing betalactams are widely used for the treatment of cows with mastitis (Mitchell et al., 1998). In the present study, beta-lactams showed the highest use frequency for the treatment of mastitis. Moreover, because intramammary infusion can deliver high concentrations of drug directly into the mammary gland, this method was frequently used for the treatment of mastitis. However, the frequent use of intramammary infusions was associated with increased risk of drug residues in milk (Allison, 1985; Booth and Harding, 1986; McEwen et al., 1991; Mitchell et al., 1998). Allison (1985) reported that $92 \%$ of drug residues in milk were caused by the use of intramammary infusions.

The SCC was reduced in cured quarters with drugs, but uncured quarters resulted in little change in SCC (Timms and Schultz, 1984; Seymour et al., 1989; Greene et al., 1991). Milk samples collected from the uncured quarters can cause higher false-positive outcomes because of high levels of natural inhibitors, compared with those of the cured quarters. Cullor et al. (1994) reported that the rates of false-positive outcome for the Delvotest assay were 3.7 and $11.1 \%$ in the milk samples with low 
Table 3. Somatic cell count of negative, false-positive, and positive samples.

\begin{tabular}{lll}
\hline & \multicolumn{2}{c}{ Somatic cell count $(\times 1000 \text { cells } / \mathrm{mL})^{1}$} \\
\cline { 2 - 3 } Samples & Before treatment & After treatment \\
\hline Negative samples $^{2}(\mathrm{n}=49)$ & $4.932 \pm 3.157$ & $2.447 \pm 1.907$ \\
False-positive $\operatorname{samples}^{3}(\mathrm{n}=21)$ & $5.821 \pm 3.587$ & $5.368 \pm 2.246$ \\
Positive samples $^{4}(\mathrm{n}=3)$ & $6.049 \pm 4.313$ & $4.752 \pm 1.074$ \\
\hline${ }^{1}$ Average $\pm \mathrm{SD}$. & \\
${ }^{2}$ Samples exhibited color-type $\mathrm{D}$ before heat treatment at $82^{\circ} \mathrm{C}$ for $5 \mathrm{~min}$. & \\
${ }^{3}$ Samples exhibited color-type $\mathrm{D}$ after heat treatment at $82^{\circ} \mathrm{C}$ for 5 min. & \\
${ }^{4}$ Samples exhibited positive results in Charm and LacTek tests.
\end{tabular}

SCC $\left(<600 \times 10^{3}\right.$ cells $\left./ \mathrm{mL}\right)$ and high SCC $\left(>600 \times 10^{3}\right.$ cell $\mathrm{s} / \mathrm{mL}$ ) obtained at $21 \mathrm{~d}$ after the first drug treatment, respectively. In addition, Van Eenennaam et al. (1993) found that the milk with positive results for the Delovtest assay (average $5.616 \times 10^{3}$ cells $/ \mathrm{mL}$ at 9 or 11 milking and $5.211 \times 10^{3}$ cells $/ \mathrm{mL}$ at $21 \mathrm{~d}$ after drug treatment) had a significantly higher SCC than the milk with negative results (average $1.891 \times 10^{3}$ cells/ $\mathrm{mL}$ at 9 or 11 milking and $1.781 \times 10^{3}$ cells $/ \mathrm{mL}$ at 21 $\mathrm{d}$ after drug treatment). Moreover, the fact that high SCC was associated with a rate of false-positive outcome for the Delvotest assay has been identified in several studies (Carlsson et al., 1989; Sischo and Bruns, 1993; Cullor et al., 1994; Kang and Kondo, 2001). Our study also identified a similar result that the SCC in false-positive samples was higher than that in negative samples (Table 3). However, Hillerton et al. (1999) suggested that there is no obvious correlation between SCC in individual quarter milk from midlactation cows and false positive of Delvotest assay by natural inhibitors.

The persistence of drug residues in milk beyond recommended withdrawal times is related to several factors, such as treatment with more than one drug by multiple routes (Oliver et al., 1990), milk production of cow (Mercer et al., 1970; Booth and Harding, 1986), type of vehicle used in drug formulation (Mercer et al., 1970), and extended dosage or excessive dosage of drugs (McEwen et al., 1992). Mercer et al. (1970) also reported that persistently high SCC was related with the prolonged excretion of drug. In our study, the prolonged excretion was identified in 3 samples, which were positive by LacTek and Charm tests. However, the prolonged excretion rates (4\%) of our study were lower than those (17 to $21 \%$ ) of previous studies using milk samples taken from cows treated by several methods such as intrauterine, intramuscular, and intramammary administration, exclusive of cows treated with more than one drug by multiple routes (Seymour et al., 1988a; 1988b; Oliver et al., 1990). These differences may be due to false-positive results that can occur in the test using the microbial growth inhibition assays, but previous studies (Seymour et al., 1988a; 1988b; Oli- ver et al., 1990) did not investigate whether the positive results were caused by drug residues or false positive results.

On the other hand, Gibbons-Burgener et al. (2001) reported that the Delvotest assay might not be useful for the detection of drug residues in individual milk samples from cows treated for mastitis because of the low positive reliability. The Delvotest assay may be applicable to individual milk samples, but in North America, it is labeled for use on bulk tank, or other commingled milk samples rather than individual cow milk samples.

The method of heat treatment to inactivate natural inhibitors can be used to prove a false-positive result in the microbial growth inhibition assays. Kosikowski and O'Leary (1963) determined that heat treatment of milk at $82^{\circ} \mathrm{C}$ for 5 min removed all natural inhibitor activity from 11 milk samples that exhibited false-positive results on disc assay, resulting in negative readings when retested. Oliver et al. (1984) found that 4 samples from cows exposed to dry cow therapy were positive by the Delvotest P assay, but only one was confirmed positive by disc assay after heat treatment. The heat treatment eliminated false-positive results, but had no effect on positive results (Kang and Kondo, 2001). In our study, 21 samples exhibiting false-positive results were negative when retested following heat treatment at $82^{\circ} \mathrm{C}$ for $5 \mathrm{~min}$. But, 3 samples containing drugs were positive after heat treatment at $82^{\circ} \mathrm{C}$ for $5 \mathrm{~min}$. Our study revealed that the positive results in the milk samples were often caused by false-positive results when drug residues were identified by the Delvotest SP assay, one of the microbial growth inhibition assays. Moreover, the test-retest system that the same test was repeated on samples with positive results resulted in a $9 \%$ decrease in true positives and in an $81 \%$ decrease of in false positives (Cullor, 1995). This system has been recommended as a method to decrease falsepositive results, but requires a lot of time and can be expensive. On the contrary, testing milk samples after heat treatment is a fast, simple, and inexpensive method. Therefore, we suggest that heat treatment be- 
fore screening tests is an effective means to reduce false-positive results in the milk samples.

\section{CONCLUSIONS}

Seventy-three milk samples over withdrawal times after the last intramammary infusion were prepared from treated quarters of cows and tested using the Delvotest SP assay. There were 24, 20, and 12 positive samples at the reading times of 150,165 , and $180 \mathrm{~h}$, respectively. All 24 positive milk samples were heated at $82^{\circ} \mathrm{C}$ for $5 \mathrm{~min}$ and retested to determine if the positive results were caused by drug residues or natural inhibitors. The fact that 21 samples were false-positive results and 3 samples were true positive results was identified after a heat treatment of $82^{\circ} \mathrm{C}$ for $5 \mathrm{~min}$. These results suggest that the positive results in the milk samples over withdrawal times were often caused by false-positive results, and that heat treatment before screening tests is an effective means to reduce falsepositive results in the milk samples.

\section{ACKNOWLEDGMENTS}

The authors thank W. H. Park, manager of the Department of Quality Control, and P. S. Choi, assistant manager of the Department of Dairy Control in Konkuk Dairy Company, for support of sample collection and technical assistance. We also thank all farmers who kindly provided milk samples and cow treatment data.

\section{REFERENCES}

Allison, J. R. D. 1985. Antibiotic residues in milk. Br. Vet. J. 141:9-16.

Andrew, S. M. 2000. Effect of fat and protein content of milk from individual cows on the specificity rates of antibiotic residue screening tests. J. Dairy Sci. 83:2992-2997.

Andrew, S. M. 2001. Effect of composition of colostrums and transition milk from Holstein heifers on specificity rates of antibiotic residue tests. J. Dairy Sci. 84:100-106.

Andrew, S. M., R. A. Frobish, M. J. Paape, and L. J. Maturin. 1997. Evaluation of selected antibiotic residue screening tests for milk from individual cows and examination of factors that affect the probability of false-positive outcomes. J. Dairy Sci. 80:3050-3057.

Booth, J. M., and F. Harding. 1986. Testing for antibiotic residues in milk. Vet. Rec. 119:565-569.

Carlsson, A., and L. Björck. 1987. The effect of some indigenous antibacterial factors in milk on the growth of Bacillus stearothermophilus var. calidolactis. Milchwissenschaft 42:282-285.

Carlsson, A., L. Björck, and K. Persson. 1989. Lactoferrin and lysozyme in milk during acute mastitis and their inhibitory effect in Delvotest P. J. Dairy Sci. 72:3166-3175.

Cullor, J. S. 1995. Antibiotic residue testing: Cowside, bulk tank, and tanker load. Pages 7-15 in Proc. National Mastitis Council Regional Meeting, Harrisburg, PA.

Cullor, J. S., A. Van Eenennaam, I. Gardner, L. Perani, J. Dellinger, W. L. Smith, T. Thompson, M. A. Payne, L. Jensen, and W. M. Guterbock. 1994. Performance of various tests used to screen antibiotic residues in milk samples from individual animals. J. AOAC Int. 77:862-870.

Cullor, J. S., A. Van Eenennaam, J. Dellinger, L. Perani, W. Smith, and L. Jensen. 1992. Antibiotic residue assays: Can they be used to test milk from individual cows? Vet. Med. 87:477-494.

Gibbons-Burgener, S. N., J. B. Kaneene, J. W. Lloyd, J. F. Leykam, and R. J. Erskine. 2001. Reliability of three bulk-tank antimicrobial residue detection assays used to test individual milk samples from cows with mild clinical mastitis. Am. J. Vet. Res. 62:1716-1720.

Greene, W. A., A. M. Gano, K. L. Smith, J. S. Hogan, and D. A. Todhunter. 1991. Comparison of probiotic and antibiotic intramammary therapy of cattle with elevated somatic cell counts. J. Dairy Sci. 74:2976-2981.

Halbert, L. W., R. J. Erskine, P. C. Bartlett, and G. L. Johnson. 1996. Incidence of false-positive results for assays used to detect antibiotics in milk. J. Food Prot. 59:886-888.

Harmon, R. J., F. L. Schanbacher, L. C. Ferguson, and K. L. Smith. 1975. Concentration of lactoferrin in milk of normal lactating cows and changes occurring during mastitis. Am. J. Vet. Res. 36:1001-1007.

Harmon, R. J., F. L. Schanbacher, L. C. Ferguson, and K. L. Smith. 1976. Changes in lactoferrin, immunoglobulin G, bovine serum albumin, and alfa-lactalbumin during acute experimental and natural coliform mastitis in cows. Infect. Immun. 13:533-542.

Hillerton, J. E., B. I. Halley, P. Neaves, and M. D. Rose. 1999. Detection of antimicrobial substances in individual cow and quarter milk samples using Delvotest microbial inhibitor tests. J. Dairy Sci. 82:704-711.

Kang, J. H., and F. Kondo. 2001. Occurrence of false-positive results of inhibitor on milk samples using the Delvotest SP assay. J. Food Prot. 64:1211-1215.

Katz, S. E. 1982. Report on antibiotics. J. AOAC 65:358-359.

Kelley, W. N. 1982. Qualitative ampule and multitest for Beta-lactam residues in fluid milk products: Collaborative study. J. AOAC 65:1193-1207.

Kosikowski, F. V., and M. O’Leary. 1963. Natural inhibitory characteristics of some Irish manufacturing milks. J. Dairy Sci. 46:89-94.

McEwen, S. A., A. H. Meek, and W. D. Black. 1991. A dairy farm survey of antibiotic treatment practices, residue control methods and associations with inhibitors in milk. J. Food Prot. 54:454-459.

McEwen, S. A., W. D. Black, and A. H. Meek. 1992. Antibiotic residues (bacterial inhibitory substances) in the milk of cows treated under label and extra-label conditions. Can. Vet. J. 33:527-534.

Mercer, H. D., J. N. Geleta, E. J. Schultz, and W. W. Wright. 1970. Milk-out rates for antibiotic in intramammary infusion products used in the treatment of bovine mastitis: Relationship of somatic cell counts, milk production level, and drug vehicle. Am. J. Vet. Res. 31:1549-1560.

Mitchell, J. M., M. W. Griffiths, S. A. McEwen, W. B. McNab, and A. J. Yee. 1998. Antimicrobial drug residues in milk and meat: Causes, concerns, prevalence, regulations, tests, and test performance. J. Food Prot. 61:742-756.

Nickerson, S. C. 1985. Immune mechanisms of the bovine udder: An overview. JAVMA 187:41-45.

Oliver, S. P., J. L. Maki, and H. H. Dowlen. 1990. Antibiotic residues in milk following antimicrobial therapy during lactation. J. Food Prot. 53:693-696.

Oliver, S. P., R. T. Duby, R. W. Prange, and J. P. Tritschler. 1984. Residues in colostrum following antibiotic dry cow therapy. J. Dairy Sci. 67:3081-3084.

Seymour, E. H., G. M. Jones, and M. L. McGilliard. 1988a. Comparisons of on-farm screening tests for detection of antibiotic residues. J. Dairy Sci. 71:539-544.

Seymour, E. H., G. M. Jones, and M. L. McGilliard. 1988b. Persistence of residues in milk following antibiotic treatment of dairy cattle. J. Dairy Sci. 71:2292-2296.

Seymour, E. H., G. M. Jones, and M. L. McGilliard. 1989. Effectiveness of intramammary antibiotic therapy based on somatic cell count. J. Dairy Sci. 72:1057-1062. 
Sischo, W. M., and C. M. Bruns. 1993. Field trial of four cowside antibiotic-residue screening tests. JAVMA 202:1249-1254.

Suhren, G., and R. Beukers. 1999. Delvotest SP for detection of cloxacillin and sulfamethoxazole in milk: IDF interlaboratory study. J. AOAC Int. 81:978-990.

Timms, L. L., and L. H. Schultz. 1984. Mastitis therapy for cows with elevated somatic cell counts or clinical mastitis. J. Dairy Sci. 67:367-371.
Tyler, J. W., J. S. Cullor, R. J. Erskine, W. L. Smith, J. Dllinger, and K. McClure. 1992. Milk antimicrobial drug residue assay results in cattle with experimental, endotoxin-induced mastitis. JAVMA 201:1378-1384.

Van Eenennaam, A. L., J. S. Cullor, L. Perani, I. A. Gardner, W. L. Smith, J. Dellinger, W. M. Guterbock, and L. Jensen. 1993. Evaluation of milk antibiotic residue screening tests in cattle with naturally occurring clinical mastitis. J. Dairy Sci.76:3041-3053. 